MEDFARM: Jurnal Farmasi dan Kesehatan, Vol. 10, No. 2, Des 2021, Hal, 39-50

e-ISSN : 2715-9957

p-ISSN: $2354-8487$

\title{
KAJIAN KELENGKAPAN RESEP SECARA ADMINISTRATIF OBAT GOLONGAN ANTIHISTAMIN DI SALAH SATU APOTEK SWASTA DI KABUPATEN SUMEDANG
}

\author{
Ida Lisni' ${ }^{1}$, Ni Nyoman Sri Mas Hartini' ${ }^{2}$, Asip Maulana Hapid ${ }^{3}$ \\ 1,2,3 Program Studi Diploma 3 Fakultas Farmasi Universitas Bhakti Kencana \\ e-mail: 1) ida.lisni@bku.com
}

\begin{abstract}
ABSTRAK
Antihistamin merupakan suatu zat yang dapat mengurangi atau menghalangi efek histamin dengan jalan memblokir reseptor histamin. antihistamin memiliki efek samping khas yaitu efek sedasi mulai dari efek tinggi hingga tidak ada efek sama sekali. Tujuan dari penelitian ini untuk mengetahui kelengkapan resep secara administratif obat golongan antihistamin di salah satu Apotek swasta di Kabupaten Sumedang pada periode Mei 2021. Penelitian ini bersifat deskriftif kuantitatif dengan menggunakan sumber data yang berasal dari resep pasien yang diambil secara retrospektif. Resep yang dikaji sebanyak 102 lembar. Hasil data kuantitatif kajian administratif resep didapat hasil untuk tanggal penulisan resep $100 \%$, identitas dokter yang terdiri dari nama 100\%, nomor SIP $100 \%$, alamat $100 \%$ dan paraf $100 \%$. Untuk identitas pasien didapatkan hasil yaitu nama $100 \%$, alamat $100 \%$, jenis kelamin $100 \%$, usia $34,32 \%$, berat badan $0 \%$. Untuk prevalensi pengunaan obat antihstamin didapat hasil sebanyak 52,95\% pengguna berjenis kelamin perempuan, sebanyak $9,80 \%$ berusia $<5$ tahun dari total resep yang mencantumkan usia dan obat yang paling banyak digunakan yaitu obat dengan kandungan cetirizin $66.67 \%$.
\end{abstract}

Kata kunci : Antihistamin, kelengkapan Administratif, Resep, Apotek.

\section{STUDY OF ADMINISTRATIVE COMPLETENESS OF RECIPES OF ANTIHISTAMINE CLASS DRUG IN ONE PRIVATE PHARMACY IN SUMEDANG REGENCY}

\begin{abstract}
Antihistamines are substances that can reduce or block the effects of histamine by blocking histamine receptors. antihistamines have typical side effects, namely sedation effects ranging from high effects to no effects at all, the purpose of this study was to determine the administrative completeness of prescriptions for antihistamine drugs at a private pharmacy in Sumedang Regency in the period May 2021. This study is descriptive quantitative. using data sources derived from patient prescriptions taken retrospectively. The recipes studied were 102 sheets. The results of quantitative data on prescription administrative studies obtained results for the date of writing the prescription 100\%, the doctor's identity consisting of 100\% name, 100\% SIP number, $100 \%$ address and $100 \%$ initials. For the patient's identity, the results were $100 \%$ name,
\end{abstract}


MEDFARM: Jurnal Farmasi dan Kesehatan, Vol. 10, No. 2, Des 2021, Hal, 39-50

e-ISSN : 2715-9957

p-ISSN: 2354-8487

$100 \%$ address, $100 \%$ gender, $34.32 \%$ age, $0 \%$ weight. For the prevalence of the use of antihistamines, it was found that $52.95 \%$ of users were female, $9.80 \%$ aged $<5$ years from the total prescriptions that included age and the most widely used drugs were drugs containing cetirizine $66.67 \%$.

Keywords: Antihistamines, Administrative Equipment, Prescription, Pharmacy.

\section{PENDAHULUAN}

Antihistamin merupakan salah satu golongan obat yang cukup familiar di kalangan masyarakat, terutama antihistamin golongan $\mathrm{H} 1$ yang kebanyakan diindikasikan untuk pengobatan antialergi. Antihistamin cukup banyak diresepkan oleh dokter-dokter baik dokter umum maupun dokter spesialis, terjadinya reaksi alergi biasanya diakibatkan karena bisa dari faktor perubahan pola hidup, riwayat pekerjaan, lingkungan dan riwayat alergi (Putri, 2019).

Antihistamin merupakan suatu zat yang dapat mengurangi atau merintangi efek histamin terhadap tubuh dengan jalan memblok reseptor histamin (Sari \& Yenny, 2018). Ditinjau dari prevalensi di seluruh dunia 12\% hingga 22\% orang pernah mengalami gejala urtikaria atau alergi dimana sekurang-kurangnya satu kali dalam seumur hidup (Sari \& Yenny, 2018). Dan salah satu obat yang sering digunakan dalam menangani alergi oleh masyarakat yaitu adalah obat antihistamin, antihistamin memiliki efek samping yang khas yaitu efek sedasi dimulai dari efek sedasi rendah hingga efek sedasi yang tinggi, sehingga perlu dilakukan pengawasan dan pengkajian terhadap resep, salah satu cara untuk menaganinya yaitu dengan pengkajian resep secara administratif.

Resep yang baik ialah resep yang mengandung informasi yang cukup yang memungkinkan Apoteker dan Tenaga Teknis Kefarmasian mengerti dan paham obat yang akan diserahkan atau diracik kepada pasien, namun kenyataannya masih banyak permasalahan yang ditemukan dalam peresepan. Persyaratan administratif, merupakan pengkajian awal pada saat resep diterima di Apotek, pengkajian administratif perlu dilakukan karena mencakup seluruh informasi di dalam resep yang terdiri dari kejelasan tulisan obat, keabsahan resep dan kejelasan informasi dalam resep baik itu identitas pasien dan identitas dokter (Megawati \& Santoso, 2017).

Pengkajian administratif resep sangatlah perlu untuk dilakukan, karena ketidaklengkapan administratif bisa menyebabkan kesalahan mulai dari 
MEDFARM: Jurnal Farmasi dan Kesehatan, Vol. 10, No. 2, Des 2021, Hal, 39-50

e-ISSN : 2715-9957

p-ISSN: 2354-8487

kesalahan ringan sampai fatal. Oleh karena itu pengkajian administratif sangatlah perlu dilakukan untuk menghindari Medication Error, menurut National Coordinating Courcil for Medication Error Reporting and Prevention (NCCMERP) Menyebutkan bahwa Medication Error adalah kejadian yang menyebabkan penggunaan obat yang tidak tepat atau membahayakan pasien selama dalam penanganan tenaga kesehatan yang sebenarnya dapat dicegah (NCCMERP, 2021). Bentuk Medication Error yang terjadi diantaranya yaitu Prescribing error, transcribing error, dispensing error dan administration error (Khairurrijal \& Putriana, 2018). Kesalahan dalam tahap prescribing error dan dispensing error merupakan dua hal yang sering terjadi dalam kesalahan pengobatan (Maalangen et al., 2019). Dampak dari kesalahan tersebut sangat bergam mulai dari tidak memberi resiko sama sekali sampai terjadi kecatatan bahkan kematian, menurut institute of medicine USA memperkirakan medication error menjadi penyebab 7000 kematian di USA pertahun.

Berdasarkan masalah tersebut, maka dilakukan penelitian pengkajian resep terhadap kelengkapan administrasifnya dan dilihat apakah kelengkapan administratifnya sudah lengkap atau tidak. Penelitian ini dilakukan di salah satu Apotek swasta di Kabupaten Sumedang, sampel dari penelitian ini adalah resep yang mengandung obat golongan Antihistamin. Sampel resep yang diambil yaitu kumpulan resep pada periode Mei 2021.

\section{METODOLOGI PENELITIAN}

Penelitian ini berjudul "Kajian Kelengkapan Resep Secara Administratif Obat Golongan Antihistamin di Salah Satu Apotek Swasta di Kabupaten Sumedang", berdasarkan data resep yang diambil pada periode Mei 2021. Jenis penelitian yang dilakukan merupakan penelitian observasional dengan metode deskriftif kuantitatif dan menggunakan data retrospektif. Deskriftif kuantitatif adalah metode penelitian yang memberikan gambaran atau deskripsi mengenai kelengkapan resep secara administratif penggunaan obat antihistamin yang didasarkan dari data resep di Apotek periode Mei 2021. Sedangkan retrospektif yaitu penelitian didasarkan dengan melihat data pada periode sebelumnya. Cara pengambilan data yaitu diambil dari lembaran resep obat yang mengandung 
MEDFARM: Jurnal Farmasi dan Kesehatan, Vol. 10, No. 2, Des 2021, Hal, 39-50

e-ISSN : 2715-9957

p-ISSN: 2354-8487

obat golongan Antihistamin di salah satu Apotek swasta di Kabupaten Sumedang pada periode Mei 2021. Kemudian dilakukan pengkajian administratif yang meliputi Identitas dokter (nama, nomor SIP, alamat dan paraf), tanggal penulisan resep dan identitas pasien (nama, alamat, usia, jenis kelamin dan berat badan).

\section{HASIL DAN PEMBAHASAN}

Hasil penelitian yang didapat dari seluruh resep selama periode Mei $2021 \mathrm{di}$ salah satu Apotek swasta di Kabupaten Sumedang. yaitu, pada penelitian ini di dapat sampel resep sebanyak 102 lembar resep yang mengandung obat golongan antihistamin dari total keseluruhan resep bulan Mei yaitu sebanyak 1012 resep.

Hasil penelitian yang diambil yaitu meliputi jumlah kelengkapan resep secara administratif (identitas dokter nama, nomor SIP, alamat dan paraf, tanggal penulisan resep dan identitas pasien nama, alamat, usia, jenis kelamin dan berat badan) dan prevalensi penggunan obat antihistamin yang terdiri dari nama obat, jenis kelamin dan usia pasien.

Penelitian ini dilakukan yaitu untuk mengetahui, bagaimanakah kelengkapan resep secara administratif terutama obat golongan antihistamin di Apotek di daerah Kabupaten Sumedang pada periode Mei 2021, skrining resep merupakan suatu langkah pertama yang dilakukan oleh petugas kefarmasian ketika resep diterima maka dari itu perlusekali dilakukan penelitian. Pada pengkajian resep ini digunakan acuan sebagai pedoman yaitu Peraturan Mentri Kesehatan RI Nomor 72 tahun 2016 tentang Standar Pelayanan Kefarmasian di Apotek dimana dilihat kajian resep secara administratif.

Tabel 1. Kelengkapan administratif resep secara keseluruhan

\begin{tabular}{cccc}
\hline No. & Kelengkapan Administratif Resep & $\Sigma$ Resep (N=102) & $\Sigma$ Persentase (\%) \\
\hline 1. & Lengkap & 0 & $0 \%$ \\
2. & Tidak lengkap & 102 & $100 \%$ \\
\hline & Jumlah & 102 & $100 \%$ \\
\hline
\end{tabular}


MEDFARM: Jurnal Farmasi dan Kesehatan, Vol. 10, No. 2, Des 2021, Hal, 39-50 e-ISSN : 2715-9957

p-ISSN: 2354-8487

Pada tabel diatas kelengkapan administratif resep secara keseluruhan menunjukan, kelengkapan resep di Apotek yaitu menunjukan resep yang tidak lengkap sebanyak $100 \%$ dan resep yang lengkap yaitu 0\%. ketidak lengkapan resep ini kebanyakan berasal dari berat badan dan usia pasien yang tidak dicantumkan dalam penulisan resep.

Tabel 1. Kelengkapan Administratif Resep Obat Golongan Antihistamin di Apotek Periode Mei 2021

\begin{tabular}{llcccc}
\hline \multirow{2}{*}{ No } & $\begin{array}{c}\text { Kelengkapan Administratif } \\
\text { resep }\end{array}$ & & \multicolumn{2}{c}{$\sum$ Resep (N=102) } & \multicolumn{2}{c}{$\sum$ Persentase (\%) } \\
\cline { 3 - 6 } & & Ada & Tidak & Ada & Tidak \\
\hline 1. & Tanggal penulisan resep & 102 & 0 & $100 \%$ & $0 \%$ \\
2. & Nama dokter & 102 & 0 & $100 \%$ & $0 \%$ \\
3. & SIP dokter & 102 & 0 & $100 \%$ & $0 \%$ \\
4. & Alamat dokter & 102 & 0 & $100 \%$ & $0 \%$ \\
5. & Paraf dokter & 102 & 0 & $100 \%$ & $0 \%$ \\
6. & Nama pasien & 102 & 0 & $100 \%$ & $0 \%$ \\
7. & Alamat pasien & 102 & 0 & $100 \%$ & $0 \%$ \\
8. & Usia/tanggal lahir pasien & 35 & 67 & $34.32 \%$ & $65.68 \%$ \\
9. & Jenis kelamin pasien & 102 & 0 & $100 \%$ & $0 \%$ \\
10. & Berat badan/tinggi badan & 0 & 100 & $0 \%$ & $100 \%$ \\
\hline
\end{tabular}

Berdasarkan pada tabel diatas, persentase kelengkapan administratif resep di apotek, yaitu didapat hasil tanggal penulisan resep 100\%, nama dokter $100 \%$, nomor SIP dokter 100\%, alamat dokter 100\%, paraf dokter $100 \%$, nama pasien $100 \%$, alamat pasien $100 \%$, jenis kelamin $100 \%$, usia $34.32 \%$ dan berat badan pasien $0 \%$.

Tanggal penulisan resep perlu dicantumkan dalam sebuah resep karena tanggal penulisan resep ini bertujuan untuk keamanan pasien dalam hal pengambilan obat, Apoteker dapat menentukan apakah resep tersebut masih bisa dilayani di apotek atau disarankan kembali ke dokter yang berkaitan (Megawati \& Santoso, 2017). dan juga penulisan tanggal resep yaitu untuk 
MEDFARM: Jurnal Farmasi dan Kesehatan, Vol. 10, No. 2, Des 2021, Hal, 39-50

e-ISSN : 2715-9957

p-ISSN: 2354-8487

manajemen di apotek sendiri. Yaitu, untuk pengarsipan apotek, sehingga perlu untuk dilakukan penulisan tanggal resep. Kelengkapan penulisan tanggal resep di apotek tempat dilakukan penelitian yaitu didapat hasil penulisan tanggal resep 100\% memenuhi persyaratan administratif, karena pada seluruh jumlah 102 resep terdapat semua tanggal penulisan resep.

Identitas dokter mencakup nama dokter, nomor SIP dokter, alamat dokter dan paraf dokter. Identitas dokter merupakan hal terpenting dalam sebuah resep, nama dokter harus/wajib dicantumkan agar apoteker dan tenaga kefarmasian mengetahui pasien tersebut berasal dari dokter mana dan apabila terjadi kekurangjelasan atau adanya kekosongan obat, tenaga kefarmasian bisa langsung menghubungi dokter tersebut. Begitu juga nomor SIP dokter, sangatlah perlu untuk dicantumkan karena fungsi dari SIP untuk menjamin keamanan pasien bahwa dokter bersangkutan mempunyai kewenangan untuk menuliskan resep dan dokter pun dilindungi oleh undang-undang. Alamat dokter, sangatlah perlu untuk di cantumkan dengan tujuan agar apabila terjadi keraguan atau kesalahan dalam penulisan resep petugas farmasi baik Apoteker maupun Tenaga Teknis Kefarmasian (TTK) bisa langsung menghubungi atau menghampiri dokter yang bersangkutan. Begitu juga dengan paraf dokter, dimana paraf dokter ialah bukti atau ciri dan sebagai suatu tanda keabsahan dari resep tersebut dan juga agar tidak disalahgunakan oleh pasien apalagi dalam hal penulisan resep narkotika dan psikotropika (Megawati \& Santoso, 2017). Berdasarkan hasil penelitian kajian administratif identitas dokter yang mencakup nama dokter, alamat dokter, nomor SIP dokter dan paraf dokter di apotek tempat dilakukan penelitian yaitu sudah memenuhi persyaratan dari 102 lembar resep semua resep lengkap 100\% memenuhi persyaratan administratif.

Kelengkapan identitas pasien yang diteliti terdiri dari nama, alamat, jenis kelamin, usia dan berat badan. Hasil penelitian untuk nama pasien $100 \%$ lengkap dan memenuhi persyaratan administratif, dalam penulisan resep nama pasien merupakan bagian penting agar tidak terjadinya kesalahan dalam pemberian obat. Untuk alamat pasien sering kali diabaikan dalam penulisan resep, padahal alamat pasien pun sangat penting yang bertujuan untuk mengkonfirmasi kembali pasien ditakutkan ada pasien yang sama dalam hal nama terutama, kelengkapan alamat pasien yaitu didapat hasil 100\% lengkap 
MEDFARM: Jurnal Farmasi dan Kesehatan, Vol. 10, No. 2, Des 2021, Hal, 39-50

e-ISSN : 2715-9957

p-ISSN: 2354-8487

memenuhi persyaratan administratif. selain nama dan alamat ada juga jenis kelamin yang mana penulisan jenis kelamin ini bertujuan untuk menghindari kesalahan dalam pemanggilan pasien, kelengkapan jenis kelamin didapat hasil yaitu sudah memenuhi syarat $100 \%$ kelengkapan administratif.

Usia pasien dalam penulisan resep, sangatlah perlu untuk di tulis yang mana penulisan usia ini, akan berguna dalam perhitungan dosis terutama pada pasien anak-anak dan dari usia juga bisa dilihat bentuk sedian yang sesuai dengan kondisi pasien (Megawati \& Santoso, 2017), untuk persyaratan administratif usia pasien yaitu hanya ada 35 lembar resep yang menuliskan usia pasien sehingga di dapat persentasi yaitu 34.32\% dari total 102 sampel resep sehingga kurang memenuhi persyaratan administratif. Lalu yang terkhir yaitu berat badan pasien, berat badan pasien sangatlah perlu di cantumkan yang mana tujuan dari penulisan berat badan ini yaitu untuk menghitung kesesuaian dosis terutama untuk dosis anak-anak dan bayi (Megawati \& Santoso, 2017). Untuk kelengkapan administratif berat badan di apotek tempat dilakukannya penelitian yaitu di dapat hasil 0\%, karena tidak ada satu pun dalam resep yang mencantumkan berat badan dari total keseluruhan resep, sehingga seluruh resep tidak memenuhi kelengkapan resep secara administratif.

Dari keseluruhan data yang di dapat, yaitu ketidak lengkapan penulisan resep yang menyebabkan medication error, ialah ada pada kelengkapan persyaratan usia dan berat badan pasien. Usia dan berat badan dalam penulisan resep sangatlah diperlukan karena dapat digunakan sebagai acuan dalam menentukan dosis dan bentuk sediaan sesuai keadaan pasien terutama pada pasien anak-anak.

Dilihat dari sampel yang didapat, jumlah penggunaan obat antihistamin di apotek tempat dilakukannya penelitian yaitu cukup banyak yaitu ada 102 lembar resep dari total keseluruhan resep yaitu 1012 lembar atau sekitar 10.07\% dari total resep selama 1 bulan.

Tabel 2. Jumlah pasien berdasarkan jenis kelamin

\begin{tabular}{cccc}
\hline No. & Jenis kelamin & $\Sigma$ Resep (N=102) & $\Sigma$ Persentase (\%) \\
\hline 1. & Laki - Laki & 48 & $47.05 \%$
\end{tabular}


MEDFARM: Jurnal Farmasi dan Kesehatan, Vol. 10, No. 2, Des 2021, Hal, 39-50 e-ISSN : 2715-9957

p-ISSN: 2354-8487

2.

Perempuan

54

$52.95 \%$

Jumlah

102

$100 \%$

Untuk penggunaan obat antihistamin di apotek tempat dilakukannya penelitian, kebanyakan pasien yang menerima resep obat antihistamin yaitu pasien perempuan yakni sebanyak 52.95\%, sedangkan untuk laki-laki yaitu didapat hasil sebanyak $47.05 \%$. pengunaan obat antihistamin di apotek tempat dilakukannya penelitian lebih banyak digunakan oleh pasien perempuan dibandingkan dengan pasien laki-laki. Namun hal ini belum ditemukan adanya hubungan atau perbedaan dalam penggunaan obat antihistamin pada pasien laki-laki maupun pasien perempuan, karena penggunaan obat antihistamin sebagian besar disebabkan karena adanya reaksi alergi (Lisni et al., 2020). Adanya perbedaan frekuensi penyakit yang dialami oleh pasien yang didasarkan atas jenis kelamin biasanya diakibatkan karena bisa dari faktor perubahan pola hidup, riwayat pekerjaan, lingkungan dan riwayat alergi (Putri, 2019).

Tabel 3. Jumlah pasien berdasarkan usia

\begin{tabular}{cccc}
\hline No. & Usia Pasien & $\sum$ Resep (N=102) & $\sum$ Persentase (\%) \\
\hline 1. & $<5$ Tahun & 10 & $9.80 \%$ \\
2. & $5-11$ Tahun & 3 & $2.94 \%$ \\
3. & $12-25$ Tahun & 9 & $8.83 \%$ \\
4. & $26-45$ Tahun & 5 & $4.90 \%$ \\
5. & $>46$ Tahun & 8 & $7.85 \%$ \\
6. & Resep tanpa usia & 67 & $65.68 \%$ \\
\hline
\end{tabular}


MEDFARM: Jurnal Farmasi dan Kesehatan, Vol. 10, No. 2, Des 2021, Hal, 39-50

e-ISSN : 2715-9957

p-ISSN: 2354-8487

\begin{tabular}{ccc}
\hline Jumlah & 102 & $100 \%$ \\
\hline
\end{tabular}

Usia dalam penelitian kali ini yaitu, dari jumlah 102 resep yang mengandung obat antihistamin yaitu sebanyak 67 resep tidak ditulis keterangan usianya, apabila di persentasikan sebanyak $65.68 \%$ resep tidak terdapat keterangan usia sedangkan untuk resep yang terdapat usianya yaitu hanya 35 lembar resep, dari 35 resep tersebut di dapat persentasi usia $<5$ tahun $9.80 \%$, usia 5-11 tahun 2.94\%, usia 12-25 tahun 8.83\%, 26-45 tahun $4.90 \%$ dan $>46$ tahun 7.86\%. Dari total 35 lembar resep usia yang paling mendominasi yaitu usia $<5$ tahun, pada usia ini manusia dikategorikan berada pada masa bayi dimana pada masa ini terjadi peningkatan penderita pasien yang menggunakan obat antihistamin karena pada masa ini sistem imunologis dan kemampuan cadangan (daya tahan tubuh) belum sempurna dan masih lemah dan perlu penyesuaian tubuh sehingga sangat rentan terhadap berbagai penyakit dan infeksi, termasuk penyakit-penyakit yang menggunakan obat antisitamin (Nugraha , Wati, \& Kardana, 2020).

Tabel 4. Jumlah penggunaan obat antihistamin

\begin{tabular}{|c|c|c|c|}
\hline No. & Nama Obat & $\Sigma$ Resep $(\mathrm{N}=102)$ & $\Sigma$ Persentase $(\%)$ \\
\hline \multirow[t]{4}{*}{1.} & ${ }^{*}$ Cetirizin & 2 & \multirow{4}{*}{$66.67 \%$} \\
\hline & *Intrizin & 28 & \\
\hline & \multirow[t]{2}{*}{ *Tiriz } & 38 & \\
\hline & & 78 & \\
\hline 2. & Cyproheptadin *Heptasan & 25 & $24.50 \%$ \\
\hline 3. & Dimenhydrinat & 9 & $8,83 \%$ \\
\hline \multicolumn{2}{|r|}{ Jumlah } & 102 & $100 \%$ \\
\hline
\end{tabular}

Untuk penggunaan obat, obat yang paling banyak digunakan yaitu adalah obat antihistamin dengan kandungan cetirizin dengan nama dagang intrizin, tiriz dan cetirizin di dapat hasil yaitu $66.67 \%$, untuk obat yang kedua yaitu obat dengan kandungan ciproheptadin dengan nama dagang yaitu heptasan yaitu 
MEDFARM: Jurnal Farmasi dan Kesehatan, Vol. 10, No. 2, Des 2021, Hal, 39-50

e-ISSN : 2715-9957

p-ISSN: 2354-8487

didapat hasil sebanyak $24.50 \%$ dan yang terakhir yaitu obat antihistamin dengan kandungan dimenhidrinat di dapat hasil sebanyak $8.83 \%$.

Cetirizin menjadi obat yang paling banyak diresepkan di apotek tempat dilaksanakannya penelitian. Hal ini dikarenakan bahwa cetirizin merupakan obat golongan antihistamin generasi kedua dan mempunyai efek sedasi rendah atau sama sekali tidak menimbulkan efek sedasi sehingga cetirizin menjadi first line dalam pengobatan alergi pilihan nomor satu. Antihistamin generasi pertama (golongan lama) relatif mempunyai kerja pendek dan ada beberapa yang memiliki waktu kerja sampai 12 jam. Antihistamin generasi kedua (golongan baru) memiliki kerja panjang. Hampir semua golongan antihistamin generasi pertama menimbulkan efek sedasi namun efek sedasi ini kadang-kadang dibutuhkan untuk mengendalikan rasa gatal karena alergi. Tidak banyak yang menunjukan bahwa antihistamin generasi pertama lebih baik dari pada generasi kedua karena penggunaan obat pada setiap pasien itu mempunyai respons yang berbeda. Generasi kedua lebih sering digunakan mungkin karena memiliki kelebihan yaitu lebih sedikit atau sama sekali tidak menimbulkan efek sedasi dan gangguan psikomotor dibanding generasi pertama karena generasi kedua jumlah obat yang menembus sawar darah otak hanya sedikit dan bahkan sulit untuk menembus sawar otak (PIONAS, 2015).

\section{SIMPULAN}

Setelah melakukan penelitian pengkajian administratif pada resep golongan obat antihistamin di salah satu Apotek swasta di Kabupaten Sumedang pada periode Mei 2021, di dapatkan hasil yaitu dari total 102 resep, seluruh resep tidak lengkap atau tidak memenuhi syarat administratif. Dari 10 aspek pengkajian secara administratif yaitu nama dokter, alamat dokter, nomor SIP dokter, paraf dokter, tanggal penulisan resep, nama pasien, alamat pasien dan jenis kelamin pasien $100 \%$ lengkap sedangkan usia pasien hanya $34.32 \%$ dan berat badan pasien $0 \%$.

Untuk penggunaan obat antihistamin, di dapatkan hasil bahwa kebanyakan pasien yang menerima obat antihistamin berjenis kelamin perempuan (52.59\%) untuk rentang usia kebanyakan berusia $<5$ tahun sebanyak $(9.80 \%)$ dari resep 
MEDFARM: Jurnal Farmasi dan Kesehatan, Vol. 10, No. 2, Des 2021, Hal, 39-50

e-ISSN : 2715-9957

p-ISSN: 2354-8487

yang mencantumkan usia, sedangkan untuk obat antihistamin yang paling banyak diresepkan yaitu obat mengandung cetirizin (66.67\%).

\section{DAFTAR PUSTAKA}

Gunawijaya, F. (2017). Manfaat pengunaan antihistamin generasi ketiga. Jakarta: Bagian Histologi Fakultas Kedokteran Universitas Trisakti: http://www.dipa.co.id/images/article/news/newarticle/Antihistamin.pdf.

Khairurrijal, M. A. W., \& Putriana, N. A. (2018). Review : Medication Erorr Pada Tahap Prescribing, Transcribing, Dispensing, dan Administration. Farmasetika.Com (Online), 2(4), 8. https://doi.org/10.24198/farmasetika.v2i4.15020

Lisni, I., Anggriani, A., \& Puspitasari, R. (2020). Kajian Peresepan Obat Antihistamin Pada Pasien Rawat Jalan Di Salah Satu Rumah Sakit Di Bandung. Jurnal Riset Kefarmasian Indonesia, 2(2), 52-62. https://doi.org/10.33759/jrki.v2i2.77

Maalangen, T., Citraningtyas, G., \& Wiyono, W. I. (2019). IDENTIFIKASI MEDICATION ERROR PADA RESEP PASIEN POLI INTERNA DI INSTALASI FARMASI RUMAH SAKIT BHAYANGKARA Tk. III MANADO. Pharmacon, 8(2), 434. https://doi.org/10.35799/pha.8.2019.29310

Megawati, F., \& Santoso, P. (2017). Pengkajian Resep Secara Administratif Berdasarkan Peraturan Menteri Kesehatan Ri No 35 Tahun 2014. Jurnal Ilmiah Medicamento, 3(1), 12-16.

NCCMERP. (2021). National Coordinating Courcil for Medication Error Reporting and Prevention. Diambil kembali dari National Coordinating Courcil for Medication Error Reporting and Prevention: https://www.nccmerp.org/about-medication-errors

Nugraha , M., Wati, K., \& Kardana, I. (2020). Dermatitis atopi pada bayi usia 012 bulan kelahiran RSUP Sanglah Denpasar dengan riwayat atopi keluarga antara bulan Desember 2015 - Januari 2016. Intisari Sains Medis, 1045 1048: https://www.isainsmedis.id/index.php/ism/article/view/205.

Pemerintah, Indonesia. (2016). Peraturan Mentri Kesehatan Republik Indonesia Nomor 73 Tahun 2016 Tentang Standar Pelayanan Kefarmasian Di Apotek. Jakarta: Lembar Negara RI Tahun 2016.

Pemerintah, Indonesia. (2017). Peraturan Mentri Kesehatan Republik Indonesia Nomor 9 Tahun 2017 Tentang Apotek. Jakarta: Lembar Negara RI Tahun 2016. 
MEDFARM: Jurnal Farmasi dan Kesehatan, Vol. 10, No. 2, Des 2021, Hal, 39-50 e-ISSN : 2715-9957

p-ISSN: 2354-8487

PIONAS. (2015). PUSAT INFORMASI OBAT NASIONAL Badan Pengawasan Obat dan Makanan. Jakarta: BADAN POM RI:

http://pionas.pom.go.id/ioni/bab-3-sistem-saluran-napas-0/34antihistamin-hiposensitisasi-dan-kedaruratan-alergi/341.

Putri, A. S. D. (2019). Gambaran Profil Dan Faktor-Faktor Yang Mempengaruhi Kejadian Penyakit Kulit Pada Warga Yang Tinggal Di Sekitar Area Pltu, Kota Palu, Indonesia. Healthy Tadulako Journal (Jurnal Kesehatan Tadulako), 5(3), 29. https://doi.org/10.22487/j25020749.2019.v5.i3.14051

Sari, F., \& Yenny, S. W. (2018). Antihistamin terbaru dibidang dermatologi. Jurnal Kesehatan Andalas, 7(Supplement 4), 61.

https://doi.org/10.25077/jka.v7i0.924 